\title{
Legal Action on Labour Inspection Memo in Industrial Relations in Indonesia
}

\author{
Lanny Ramli and Samuel Nikodemus Kaban
}

Faculty of Law, Airlangga University, Surabaya, Indonesia

\begin{abstract}
The research purpose is to study the professional relationship between workers and employers which is called industrial relations. This is motivated by the fact that workers and employers need to synergize in the process of producing goods and services for the community. In fulfilling the purpose and object of their role and activities and the quid pro quo relationship, the stakeholders pursue different interests. Employers try to earn a maximum profit by spending the least cost possible. In contrast, workers earn the maximum results with the least minimal effort. By using the socio-legal approach, the results showed that the circumstances that exist in these two different interests are prone to conflict and prone to irregularities in legislation. The government as a regulator is obliged to provide legal protection. Legal protection from the government is manifested in the role of labor inspectors, in which they have the right to conduct inspections in a preventive and repressive manner. If there is a violation, the inspectors shall issue the inspection memo. However, the implementation of the ruling of the Constitutional Court Number 7/PUU-XII/2014 results in a new problem which is an unclear execution of the said Constitutional Court ruling about the status of workers.
\end{abstract}

Keywords: Constitutional court's ruling, employment, worker-employer, industrial relations.

\section{INTRODUCTION}

Employment is inseparable from the relationship between the worker and the employer, framed by a work agreement to be doing a favor to each other. The arrangement of the worker's relationship with the employer can be seen in Article 1601 Burgerlijk Wetboek, hereinafter referred to Indonesian Civil Code, stating the labor agreement is an agreement by which the one party, the worker, binds himself to under the other's orders (the employer's), for a certain time, doing the work by receiving wages (Tjandra, 2009; Kiswandari, 2012). The employment agreement is also stipulated in Article 1 Number (14) of Law No. 13 of 2003 on Employment (hereinafter to as Laws no. $13 / 2003$ ), states that the agreement between the worker/ labor and the employer covers the terms of employment, rights, and obligations of the stakeholders (Manning \& Roesad, 2007). The working agreement is not requested in a certain format; it can be done either verbally, with a letter of appointment by the employer, or with a letter of agreement signed by both parties (Ramli, 2008). The existing law only stipulates that if the agreement is in written form, then any cost spent including other additional charges shall be borne by the employer.

The employment agreement shall come into effect and be practiced by the stakeholders if the validity of the agreement is fulfilled about Article 1320 of the Indonesian Civil Code which states that an agreement

*Address correspondence to this author at the Faculty of Law Airlangga University, Surabaya, Jl. Dharmawangsa Dalam Selatan, Surabaya, East Java 60286, Indonesia; E-mail: Iramli.unair@gmail.com must meet the requirements of (1) mutual consent of the stakeholders subjected to the agreement, (2) the capacity to do legal act, (3) there must be a specific subject, (4) admissible causes (Nugroho et al., 2018; Hamidah et al., 2017; Tobing, 2018). The validity of the agreement as provided in Article 1320 adopted in Article 52 of Law no. 13/2003, states that the Employment Agreement shall be made based on. Mutually consensual approval, ability, or aptitude to perform legal laws and a job that has been promised and has been promised is not contrary to the public decorum, morality, and relevant governmental regulations.

The research purpose is to study the professional relationship between workers and employers which is called industrial relations. This is motivated by the fact that workers and employers need to synergize in the process of producing goods and services for the community. In fulfilling the purpose and object of their role and activities and the quid pro quo relationship, the stakeholders pursue different interests. Employers try to earn a maximum profit by spending the least cost possible. In contrast, workers earn the maximum results with the least minimal effort. Hence, it is needed a study an industrial relationship between labor and the industry in terms of socio-legal perspective.

\section{METHOD}

This research is applicable in terms of socio-legal research with purposive random sampling. The subjects of study consist of the workers and the employers in Surabaya. Mojokerto, Pasuruan, and Sidoarjo. Location settings of this research are 
industrial areas where there is a high number of factory operations, for instance: PIER (Pasuruan Industrial Estate Rembang), SIER (Surabaya Industrial Estate Rungkut), Ngoro Industrial Park (Mojokerto), SiRIE (Sidoarjo Rangkah Industrial Estate). This research used procedures by using literature, in-depth interview, and questionnaire sheets containing some questions. For data collection, the data collected from the questionnaires, and in-depth interviews will be used to identify the necessary solution.

The questionnaire was compiled for identifying the problems within the dispute, solvency formulation, and obtaining the findings. It was a self-made questionnaire containing information about workers such as sex and education, the type of dispute, and the form of dispute settlement resolution. For the research-conducting method, at first, the authors elaborate on the decision of industrial relation dispute among the worker and employer. This research obtained data from workers in a different location. After using the questionnaire, the data collection is completed by in-depth interview afterward.

Moreover, the regulations used to be examined mainly are about employment agreements under Article 56 Paragraph (1) of Law no. 13/2003 which is divided into two parts: the employment agreement made for a specified time and the employment agreement for an unspecified period. Referring to the concept of two kinds of agreement above, based on Law no.13/2003, Law no. 13/2003 assures workers to obtain justice and legal certainty of employment status. The emphasis in this reference is on the point of which the worker of specified period time status may be appointed further to work with the status of an unspecified period by the employer, under Article 59 Paragraph (7), stating that workers with a specified period status may change their status to be workers with an unspecified period status following the employer's violation of the provisions outlined in Article 59 Paragraph (1) of Law no. 13/2003, Paragraph (2), Paragraph (3), Paragraph (4), Paragraph (5), and Paragraph (6). If the Article 59 Paragraph (7) is interpreted further, it then implied that there is a system that automatically shifts the status of workers from a specified period to the unspecified period status if there is an employer's violation of Article 59 of Law No. 13/2003.

\section{RESULTS}

It should be understood that the Government has functions and duties under the law allowing it to intervene in the labor law. These interventions began to take place, starting from the making of the regulation draft, to labor inspection. Thus, disputes between workers and employers related to employment status are mediated by the Government. To this end, the Government has a special unit called the labor inspector.

Labour inspection is regulated in Law No. 23 of 1948 on Labour Supervision (State Gazette of the Republic of Indonesia of 198 Number 23), hereinafter referred to as Laws no. 23/1948 (Suryomenggolo, 2009). Article 1 Paragraph (1) of Law no. 23/1948 states that labour Inspection is held to oversee the enforcement of labour laws and regulations, in particular, gather material information on labour matters and labour conditions in the widest signification for the making of Laws and labour regulations and

\section{Amount of Labour in Surabaya}

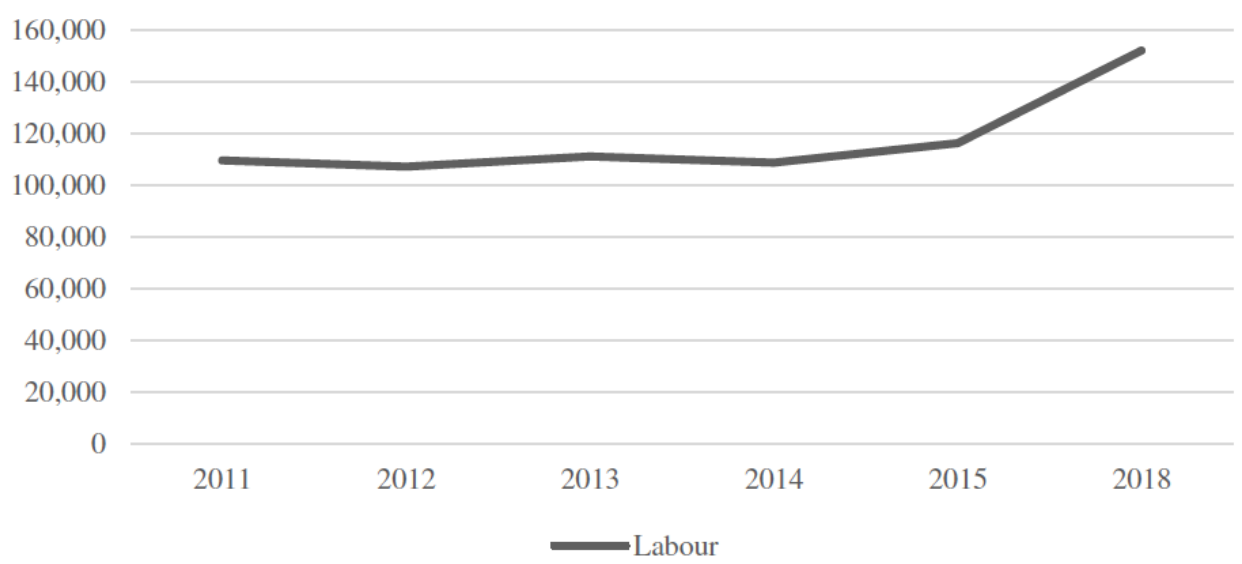

Figure 1: Amount of Labour in Surabaya.

Source: Central Bureau of Statistics of Surabaya, 2018. 
Case of Labour Demonstrations in East Java

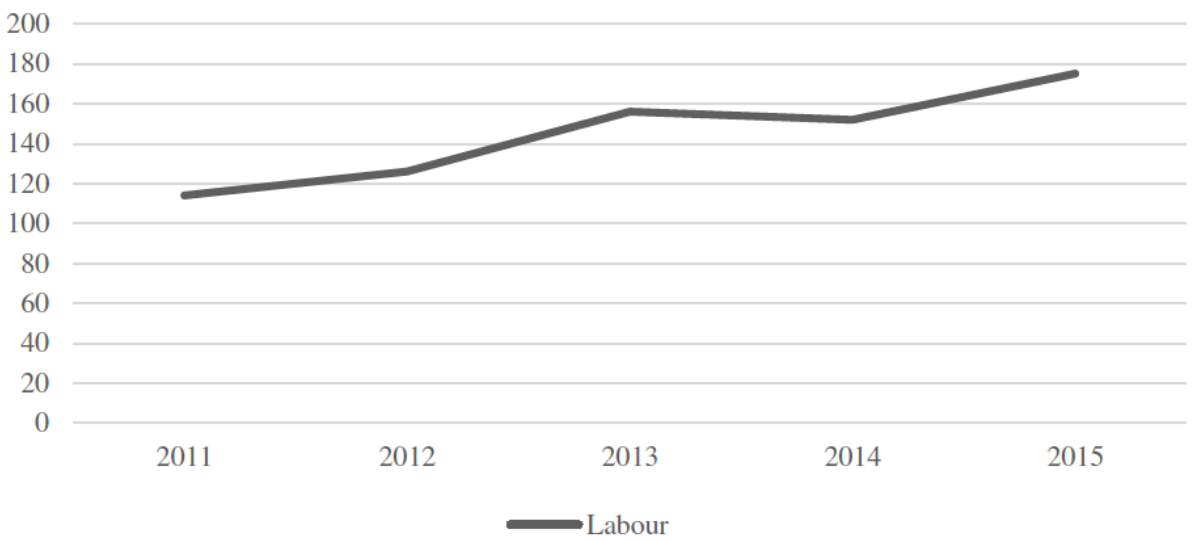

Figure 2: Case of Labour Demonstrations in East Java.

Source: Regional Police of East Java, 2016.

carry out any other assigned work by Laws or other regulations.

The labour inspectorate shall conduct an inquiry and the discovery of sufficient preliminary evidence to prove that the employer has breached the specified working period agreement to the workers. Labour inspector will issue an inspection memo to the employer to provide a warning if it is proven that the employer has committed an offence. The inspection memo contains matters relating to the result of the inspection conducted by the Labour Inspector to the companies/employer, including instructions or suggestions to eliminate violations or to implement certain labour regulations. The Labour Inspector will issue the inspection memo continuously until specified working period workers become unspecified working period workers. Problems arise when the Inspection memo is not honoured by the employer, the workers who are bound specified working period is complicated to become workers of unspecified working period status by employers even though they have fulfilled the element of Article 59 Paragraph (7) of Laws no. $13 / 2003$

In terms of authority for inspection memo's result and/or written declaration, on the consideration of the ruling of the Constitutional Court of the Republic of Indonesia No.7/PUU-XII/2014 dated November 4th, 2015, the Panel of Judges address a question of whether the Government, in this case, the Labour Inspection, has the authority to issue a written inspection and/or stipulation concerning the implementation of Article 59 Paragraph (7), Article 65

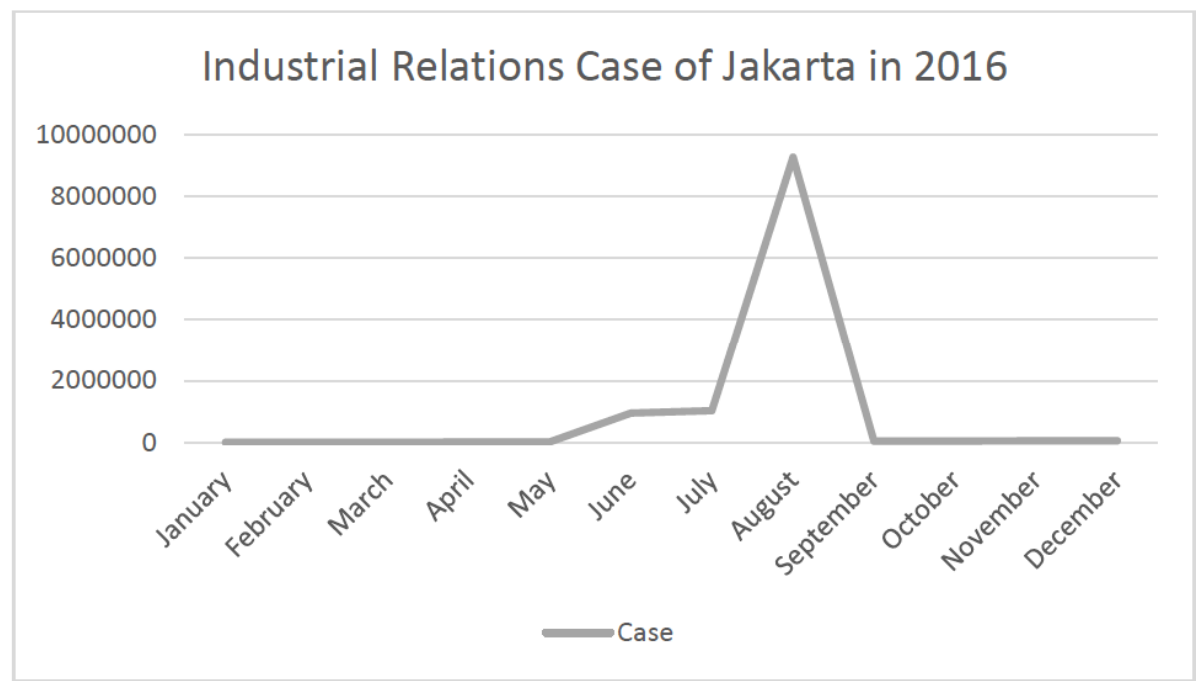

Figure 3: Industrial Relations Case of Jakarta in 2016.

Source: Jakarta OpenData at http://data.jakarta.go.id. 


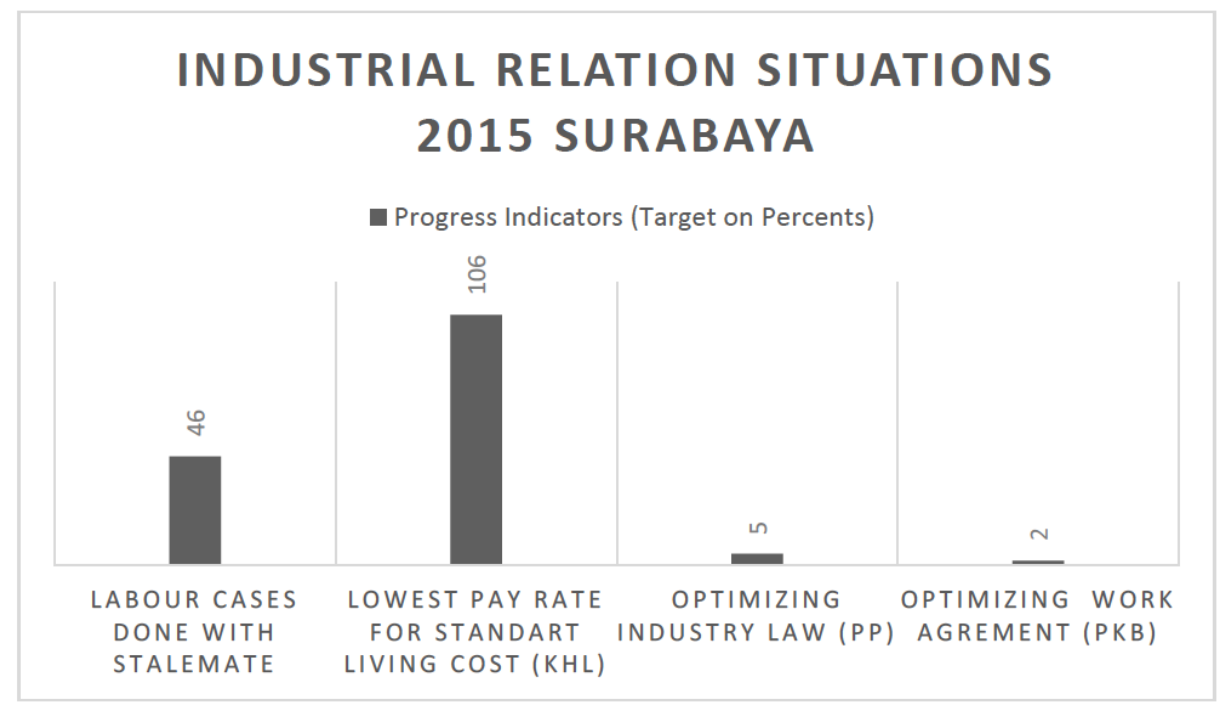

Figure 4: Industrial Relations Situations in Surabaya in 2015.

Source: Worker Agreement Year 2015.

paragraph (8), and Article 66 paragraph (4) of Laws no. 13/2003. The Court thinks that the supervision over the implementation of laws and regulations, in particular, labour-related legislation, is one of the efforts to create harmonious and fair industrial relations and to ensure law enforcement and protection for the workforce.

The purpose of labour inspection under Article 1 paragraph (1) of Law Number 3 the Year of 1951 on the Declaration of the Supervision of the Labour Control Law of 1948 NR 23 from the Republic of Indonesia to All of Indonesia (State Gazette Year 1951), hereinafter referred to as Law $3 / 1951$, is, among others, to oversee the enactment of the Law and the regulations of labour in particular (Nurjaya, 2010). This is in line with Article 1 number 32 of Law No. 13/2003 which states, that labour inspection is the activity of supervising and enforcing the implementation of the laws and regulations in the labour".

Furthermore, Article 134 of Laws no. 13/2003 states that in realizing the implementation of the rights and obligations of workers and employers, the government shall exercise supervision and enforcement of labour laws and regulations. Moreover, Indonesia has ratified the ILO Convention No. The ILO Convention No. 81 concerning Labour Inspection in Industry and Commerce, hereinafter referred to ILO Convention No. 81, in accordance with the principle of pacta sunt servanda (Lekkas \& Tzanakopoulos, 2014), Indonesia bears international legal obligation to comply with the provisions of the ILO Convention, the provisions of the present Covenant, one of which is the provision of a labour inspection system in the workplace which shall be applied throughout the workplace under the legislation, whose oversight is exercised by the Government. Article 176 of Laws no. 13/2003 states that labour inspection is performed by competent and independent labour inspectors to ensure the implementation of labour laws and regulations. Based on the aforementioned provision, according to the consideration of the Constitutional Court, it is clear that the law authorizes the Government, in this case, labour inspectors, to oversee the implementation of labour law.

Furthermore, the Constitutional Court declares that in the framework of the exercise of the authority to oversee the implementation of labour law, labour inspectors may issue written memo of examination and/or stipulation. Although both are issued by labour inspectors, there are significant differences between the nature of inspection memo and the written declaration of labour inspector workers. The inspection note shall contain matters concerning the results of inspection of the worker's inspection officer toward the employer or the hiring corporation in which also cover the instructions to prevent the violation or to comply with the labour regulations. Therefore, the inspection memo essentially resembles a recommendation and does not have an executorial nature.

In terms of Binding Capacity of Inspection Memo and Written Declaration, the concern of the workers addressed in the Constitutional Court Decision Number 7/PUU-XII/2014 is that the workers witness the hiring person who commits a crime against the norms regulated in Law no. 13/2003, may end up receiving 
the criminal sanction of imprisonment and fines according to Article 183 Paragraph (1) of Law no. 13/2003, Article 184 Paragraph (1) of Law no. 13/2003, Article 185 Paragraph (1) of Law no. 13/2003, Article 186 Paragraph (1) of Law no. 13/2003, Article 187 Paragraph (1) of Law no. 13/2003, Article 188 (1) of Law no. 13/2003 and Article 189 of Law no. 13/2003 whose procedures for settlement are regulated in Article 182 of Law no. 13/2003, by the Investigator of the State Police Official of the Republic of Indonesia and the Labour Inspector as a Civil Servant Investigator (Wijaya, 2017).

In addition, the deviation of the norm without elements of criminal Laws in Law no. 13/2003 may also be committed by the employer by ignoring the norm prescribed in Law no. 13/2003 when the employer has been sent with an inspection memo and a written declaration memo by the agency in charge, that is the labour inspection officer who deals with labour affairs at the central government, provincial and district/city governments, as referred to in Article 176 of Law no. 13/2003, Article 177 of Law no. 13/2003, Article 178 Paragraph (1) of Law no. 13/2003 and Law no. 13/2003. If the employer ignores the inspection note, then the labour inspection officer will issue a written declaration which is to be approved by the local District Court. This enables the workers as an applicant to request a judicial review to obtain fair recognition, assurance, protection, and legal certainty to become satisfied. The concern of the clients is granted by the Constitutional Court's Judge Council which declares to decide that the client's concern is pro justitia (as in Article 59 Paragraph (7), Article 65 Paragraph (8), Article 66 Paragraph (4) of Law no. 13/2003) to be showing a case of deviation to the Constitution of 1945 , as long as it is not signified as workers/labours may request to have the labour inspection officer's inspection memo approved by the local district court on condition. First, bipartite negotiations have been held but the negotiations have not reached an agreement or one of the parties refuses to negotiate. Second, inspection has been conducted by the labour inspection officer adhered to the existent laws and regulations.

Based on the Constitutional Court's ruling as mentioned above, workers have space or path to create legal certainty to the status of their job, from initially specified working period to be unspecified working period. Such legal certainty must first be based on the prevailing laws and regulations, especially Law no. $13 / 2003$ and other related legislation.
On the other hand, the Constitutional Court's Ruling as above also raises the question for the employer, among others, what law may be filed by the hiring employer at a time where the inspection memo issued by the inspector is false, in a way that it contains some elements of inaccuracy that become an unfair disadvantage. Therefore, a description of the law that can be undertaken by the employer in adherence to the provisions of Article 59 Paragraph (7), Article 65 Paragraph (8), and Article 66 Paragraph (4) of Law no. 13/2003 from Constitutional Court of Republic of Indonesia's ruling Number 7/PUU-XII/2014 dated November 4, 2015.

In the situation of difference between requesting approval with requesting execution of inspection memorandum, the memo about the implementation of the provisions of Article 59 Paragraph (7), Article 65 Paragraph (8), and Article 66 Paragraph (4) of the Law of the Republic of Indonesia No. 13 of 2003 on labour workforce (hereinafter referred to as Law 13/2003) principally explains all the information given away by the employer and worker, as well as the records from labour inspection officer regarding the implementation of the Laws on the procedure to change specified working period status into the unspecified working period.

The ratio decidendi of Constitutional Court of the Republic of Indonesia's Ruling Number7/PUU-XII/2014 dated November 4, 2015, the inspection memo contains matters concerning the results of an inspection by inspection officer against employer or hiring corporation in which also include instructions to prevent violations and to enforce labour regulations. Therefore, the Constitutional Court thinks that the nature of the inspection memo is a recommendation and does not have an executorial nature. In accordance to the Decision of Constitutional Court of the Republic of Indonesia Number 7/PUU-XII/2014 dated November 4, 2015, the consideration of decision or the rationale for the decision has mentioned two (2)terms, namely: the term "implementation of inspection memo" and the term "enactment of inspection memo". According to the Court, to enforce the implementation of labour provisions as well as to provide protection and legal certainty for workers, employers, and employers as guaranteed in Article 28D Paragraph (1) of the 1945 Constitution, workers may request the implementation of the inspection memo to the District Court. On the other hand, workers may request the enactment of inspection memo of employment/labour's inspectors to the District Court on 
condition that a) the bipartite negotiations (shall refer to a communication and consultation forum on matters about industrial relations in an enterprise whose members consist of employers and trade/labour unions that have been registered at a government agency responsible for manpower affairs or workers' representatives) have been held but the bipartite negotiations have not reached an agreement or one of the parties refused to negotiate and b) inspection by the labour inspector has been conducted based on the laws and regulations.

Both terms as mentioned above clearly have differences. The term "implementation of inspection memo" is closely related to the execution of a verdict that has a permanent legal force which in the judgment must contain condemnatory verdict, while the term "enactment of inspection memo" is closely related to the filing of cases in volunteer, where the endorsement product is a determination declaratory, that is to affirm the legal state as contained in the inspection note. Not all decisions that already have the power of law must be executed because all that needs to be done are condemnatory decisions, which contains a command to fulfil to do certain activities as explained in the verdict (Sutantio \& Oeripkartawinata, 1997). With such differences, it certainly should be distinguished on the difference of the terms "implementation of inspection memo" with the term "enactment of inspection memo".

The right to request the enactment of the inspection memo, in principle, shall apply to both the workers and the employers. In practice, a request for the implementation of an inspection memo is necessary if there are urgent reasons. For employers, the request for the implementation of the inspection memo becomes very important in the case where there is a legal fact that the working relationship between the workers and workers, which was originally based on specified working period agreement, has been assessed as a working relationship based on the unspecified working period agreement. In the case of the employer, the request for the implementation of the inspection memo becomes very important to protect the right of employers in their working relationship with the workers under the specified working period agreement. If the inspection memo is enacted and/or implemented.

In terms of Enactment of Inspection Memo, after the pronouncement of Decision of the Constitutional Court of the Republic of Indonesia Number 7/PUU-XII/2014, there are several amendments to provisions in Law no.
$13 / 2003$ stating that workers may request the enactment of inspection memo to the local District Court on condition. The bipartite negotiations have been held but the bipartite negotiations have not reached an agreement or one of the parties refused to negotiate. Inspection by the inspector has been conducted based on the laws and regulations.

Article 50 of the General Courts Act states that the District Court has the duty and authority to examine, decide, and settle criminal and civil cases in the first instance. It should be noted, however, that the enactment of the related inspection documents stated in Article 59 Paragraph (7), Article 65 Paragraph (8), and Article 66 Paragraph (4) of Law 13/2003 are regarding the special dispute since such Articles are included as provisions regulated under the labour law. About the dispute on the matter of labour law, the authority of the court to examine and decide the industrial relation shall be given to the Industrial Relation Court. The enactment of the inspection memo concerning the implementation of Article 59 Paragraph (7), Article 65 Paragraph (8), and Article 66 Paragraph (4) of Law 13/2003, stipulated by the Industrial Relations Court, can determine whether the specified working period agreement which has been made between employers and workers should or should not be changed into unspecified working period agreement or vice versa. Therefore, on the verdict of the courts relating to the enactment of the inspection memo, the parties (e.g. employers and workers) shall carry out the matters specified in the inspection memo.

It is worth to be noted that the application by the parties to enact the inspection memo is included in the category of the case with the voluntary character. It has the distinctive feature of a voluntary petition, meaning that the subject matter of the case is of one-sided interest. In principle, this case has the function purely to settle the applicant's interest in a matter that requires legal certainty (Harahap, 2008). The decision of the Court has the declarative character, meaning that the content of the decision is explaining or declaring what is being decided as legitimate (Mertokusumo, 1998). In a declaration decree, it does not have nor require a coercive measure, since it already has legal consequences without coercing the losing party in the Court to directly execute it; the decision only has the binding power (Mertokusumo, 1998).

After the application of annulment or amendment, the Court shall determine the decision. The determination of the Court in regards to the enactment 
of the inspection memo consists of 2 (two) possibilities. First, the Court may decide in regards to the enactment of inspection memo which validates the change in the status of workers, which formerly based on the specified working period agreement into an unspecified working period agreement or the determination of the Court emphasizing the status of workers to remain based on the specified working period agreement. The determination by the Court is important to confirm the certainty of the status of workers. In the case when the employer is reluctance to enforce a court ruling that enacting the inspection memo, it cannot be requested for execution and can only be resolved through the termination of an employment lawsuit.

\section{CONCLUSION}

The results showed that the parties who are to object to the determination by the Court on the enactment of the inspection memo can apply for a remedy. The existence of a legal remedy has the purpose to propose an annulment or amendment of the inspection memo if the memo is found to be disadvantageous for one of the parties (employers and/or workers). Article 110 of Law no. 2/2004 stipulates that disputes over rights and disputes concerning the dismissal of work will automatically have a permanent legal force in the absence of a request for an appeal to the Supreme Court within no later than 14 (fourteen) working days. Upon the determination on the enactment of the inspection memo, the parties can submit an appeal. One of the parties or parties who wish to file an appeal must submit it in writing through the Secretariat of Industrial Relations Court in the District Court. If the Supreme Court's decision on the appeal level has an objection from the litigant, a further legal review may be filed. Under of the Supreme Court Law, the Supreme Court may examine and decide on the legal review requested by the parties, as the final and binding decision.

\section{REFERENCES}

Hamidah, S., Bakri, M., Budiono, A. R., \& Winarno, B. (2017). The Harmonization of Islamic Law and Civil Code in the
Murabahah Contract: A Case in Indonesia. JL Pol'y \& Globalization, 58, 112.

Harahap, M. Y. (2008). Civil Procedure Law Regarding Lawsuit, Trial, Confiscation, Evidence and Court Decision. Jakarta: Sinar Grafika.

Kiswandari, M. (2012). The Manpower Aspect in the Field of Sports. Indon. L. Rev., 2, 243. https://doi.org/10.15742/ilrev.v2n3.20

Lekkas, S. I., \& Tzanakopoulos, A. (2014). Pacta sunt servanda versus Flexibility in the Suspension and Termination of Treaties. In Research Handbook on the Law of Treaties. Edward Elgar Publishing. https://doi.org/10.4337/9780857934789.00020

Manning, C., \& Roesad, K. (2007). The Manpower Law of 2003 and its implementing regulations: Genesis, key articles and potential impact. Bulletin of Indonesian Economical Studies, 43(1), 59-86. https://doi.org/10.1080/00074910701286396

Mertokusumo, S. (1998). Indonesian Civil Procedure Law. Yogyakarta: Liberty

Nugroho, A., Sulistyowati, E., \& Hikmah, N. (2018, January). A juridical review of partnership agreements that have the elements of work agreements in Indonesia. In Journal of Physics: Conference Series (Vol. 953, No. 1, p. 012169). IOP Publishing. https://doi.org/10.1088/1742-6596/953/1/012169

Nurjaya, I. N. (2010). Indonesian Labour Law Development and Reform: The Years of Ratifying Fundamental Human Rights Defined within the ILO Core Conventions. US-China Law Review, 7, 42.

Regional Police of East Java. (2016). Case of Labour Demonstration in East Java. Surabaya: Polda Jatim

Ramli, L. (2008). Labor law. Airlangga University Press.

Central Bureau of Statistics Indonesia. (2018). Amount of Labour in Surabaya (2011-2018). Surabaya: Statistic of Surabaya (BPS)

Suryomenggolo, J. (2009). Labour Law without 'Rights' in Indonesia: The Making of Undang Undang Kerdja 1948. International Journal of Comparative Labour Law and Industrial Relations, 25(4), 357-378.

Sutantio, R., \& Oeripkartawinata, I. (1997). Civil Procedure Law In Theory and Practice. Bandung: Mandar Maju.

Tjandra, S. (2009). Understanding Workers' Law Reform in Indonesia, 1998-2004. Labour and Management in Development, 9.

Tobing, C. N. (2018). Menggagas pengadilan hubungan industrial dalam bingkai ius constituendum sebagai upaya perwujudan kepastian hukum dan keadilan/Initiating an industrial relations court in the framework of ius constituendum as an effort to realize legal certainty and justice. Jurnal Hukum dan Peradilan, 7(2), 297-326.

https://doi.org/10.25216/JHP.7.2.2018.297-326

Wijaya, M. S. T. (2017). Executorial Nature of the Special Inspection Note for Labor Inspection Employees (Juridical Study of the Minister of Manpower Regulation Number 33 Year 2016 Concerning Labor Inspection Procedures. (Doctoral dissertation, Brawijaya University).

\footnotetext{
Received on 14-01-2021 Accepted on 16-02-2021 Published on 11-03-2021

https://doi.org/10.6000/1929-4409.2021.10.78

(C) 2021 Ramli and Kaban; Licensee Lifescience Global.

This is an open access article licensed under the terms of the Creative Commons Attribution Non-Commercial License (http://creativecommons.org/licenses/by-nc/3.0/) which permits unrestricted, non-commercial use, distribution and reproduction in any medium, provided the work is properly cited.
} 